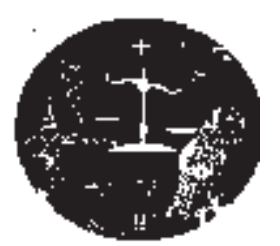

\title{
TrANSFORMAÇÕES NA ECONOMIA BRASILEIRA A PARTIR DOS ANOS 90 - COMÉRCIO BILATERAL COM a Argentina 1991/2011
}

DOI: $10.12957 /$ synthesis.2015.25833

\section{ana Claudia Nogueira Bertolino*, Caio Peixoto Chain** e Cezar Augusto Miranda Guedes***}

\begin{abstract}
Resumo: As últimas décadas do século passado foram marcadas internacionalmente pelo aprofundamento de processos interligados que transformaram, em grande medida, a dinâmica social e econômica em escala mundial. Além da aceleração dos processos inovativos e da formação de blocos regionais, evidenciou-se o incremento de distintas formas de internacionalização da produção: comércio, investimento direto estrangeiro e relações contratuais. O comércio constitui variável imprescindível para a dinâmica econômica e para uma maior integração internacional. Apenas em 2011, o comércio exterior brasileiro registrou recorde de US\$ 482,3 bilhões. As exportações e importações encerraram o período com resultados igualmente recordes. A Argentina figura em terceiro lugar no fluxo de exportações e importações brasileiras. Além disso, juntos, Brasil e Argentina cumprem papel fundamental em sua região, potencializado via Mercosul. O cenário tem evoluído para um fortalecimento mútuo na medida em que são criadas formas mais soberanas de inserção internacional, onde a soma das partes tende a ser maior que seus componentes em separado.
\end{abstract}

Palavras-chave: Comércio Brasil-Argentina. Balança Comercial. Mercosul.

\section{Transformations in the brazilian economy from the 90`s - Bilateral trade with Argentina 1991/2011}

Abstract: The last decades of the past century were internationally marked by the deepening of interconnected processes that transformed in a large extent, the social and economic dynamics global scale. Beyond the innovative processes and the formation of regional blocs are accelerating, it was noted the increase in different forms of production's internationalization: trade, foreign direct investment and contractual relations. The trade was always essential for economic dynamics and for a greater international integration. Only in 2011, Brazilian foreign trade registered record of US\$ 482,3 billion. Exports and imports ended the period with record results. Argentina is in the third in both the flow of Brazilian exports and imports. Furthermore, together, Brazil and Argentina play a critical role in its region, boosted by the action in the space of Mercosur. The scenario has evolved into a mutual strengthening in a moment that sovereign forms of international insertion are created, where the sum of the parts tends to be higher than its components separately.

Keywords: Brazil-Argentina Trade. Trade Balance. Mercosur.

\footnotetext{
* Mestranda em Economia pela Universidade do Estado do Rio de Janeiro (UERJ).

** Doutorando em Administração pela Universidade Federal de Lavras (UFLA).

*** Professor Associado do Departamento de Ciências Econômicas da Universidade Federal Rural do Rio de Janeiro (UFRRJ).
} 


\section{INTRODUÇÃO}

Desde as últimas décadas do século passado vivemos em um cenário marcado pelo aprofundamento de três processos que produzem uma mudança substancial na dinâmica social e econômica em escala global: um novo ciclo de inovações radicais, a difusão de várias formas de integração regional e a intensificação das formas de internacionalização da produção (GUEDES, 2009). No que tange ao presente trabalho, importam as referidas formas básicas de internacionalização da produção, em número de três: comércio, investimento externo direto e relações contratuais (DUNNING, 1977).

Segundo Gonçalves (2005), o comércio significa que a mercadoria, bem ou serviço é produzido no país de origem e exportado cruzando a fronteira nacional, enquanto o investimento direto externo (IDE) representa o deslocamento de pessoa jurídica, a empresa - a presença comercial. Desse modo, sempre que um não residente realiza investimento direto com o objetivo de controlar a empresa receptora do capital, há IDE (filial, subsidiária ou joint venture). Ainda segundo a mesma classificação, as relações contratuais, construídas por meio de franquias, licenças ou contratos, regulam as transferências de ativos, como tecnologias referentes a processos produtivos ou a produtos específicos.

Com o intuito de caracterizar o presente trabalho, ressalta-se a primeira forma de internacionalização da produção, o comércio, e nessa lógica, o comércio bilateral Brasil - Argentina, com seus constituintes quantitativos e qualitativos. A Argentina figura em terceiro lugar tanto na pauta das importações, quanto na das exportações brasileiras e, juntos, os dois países cumprem papel fundamental em sua região. Argentina e Brasil são os maiores países sul-americanos e têm recursos naturais disponíveis como em poucos lugares do mundo. Eles talvez sejam os únicos que podem aumentar simultaneamente a produção de alimentos e da agroenergia, fonte renovável por definição em que se destacam o biodiesel e etanol (GUEDES; SILVA, 2011).

O cenário nos últimos anos é de maior visibilidade para as duas economias, em um momento de turbulência internacional, ao mesmo tempo em que as duas nações se aproximam, apesar de algumas barreiras impostas e períodos de certa paralisia na relação bilateral.

Em entrevista para o jornal argentino Página 12, de março de 2012, Mercedes Marcó del Pont, presidenta do Banco Central da República Argentina (BCRA), inovou ao incluir o Brasil como variável para a economia argentina, evidenciando, dessa forma, a importância das relações com o país vizinho. Ao falar da ampliação das funções do Banco Central, disse que mudará a equação de análise da relação entre moeda, reservas e contas externas. Segundo ela, as fórmulas convencionais deixam de lado um conjunto de aspectos qualitativos inerentes à realidade econômica argentina, como a evolução da economia mundial, o comportamento dos preços das principais exportações e o nível de atividade no Brasil.

\section{ConsideraÇões SOBRE O COMÉRCIO BRASILEIRO}

O comércio constitui variável imprescindível para a dinâmica econômica e para uma maior integração internacional. Apenas em 2011, o comércio exterior brasileiro registrou recorde de US $\$ 482,3$ bilhões, com ampliação de $25,7 \%$ sobre 2010, quando atingiu US\$ 383,7 bilhões. As exportações encerraram o período com valor de US \$ 256 bilhões e as importações, de US\$ 226,2 bilhões, resultados igualmente recordes. Em relação a 2010, as exportações apresentaram crescimento de $26,8 \%$ e as importações, $24,5 \%$. O saldo comercial atingiu US $\$ 29,8$ bilhões, significando ampliação de $47,9 \%$ sobre o mesmo período de 2010, de US\$20,1 bilhões, motivado por um maior aumento das exportações em relação às importações. Estes crescimentos significativos indicam a solidez da progressiva inserção brasileira no comércio internacional. Com o objetivo de avaliar mais profundamente a relação comercial da qual se trata o presente trabalho, uma análise geral das características do comércio brasileiro é apresentada. Segundo publicações da Secretaria de Comércio 
Exterior (SECEX), vinculada ao Ministério do Desenvolvimento, Indústria e Comércio Exterior, o Brasil se apresentou como a $6^{a}$ maior economia de 2011, ultrapassando o Reino Unido e ficando atrás apenas de Estados Unidos, China, Japão, Alemanha e França. O país ainda figurou como um dos maiores importadores e exportadores mundiais do mesmo ano, respondendo por cerca de $1,3 \%$ do volume transacionado em importações e 1,4\% em exportações, razão pela qual o comércio como forma de internacionalização da produção constitui variável de notável importância para a análise da economia do país. Os referidos dados podem ser confirmados nas Tabelas 1 e 2.

Tabela 1-Maiores importadores mundiais - 2011

\begin{tabular}{|c|c|c|}
\hline \multicolumn{3}{|c|}{ Maiores exportadores mundiais - 2011 (em US\$ bilhões) } \\
\hline Posição & País & Valor \\
\hline 1 & China & 1.899 \\
\hline 2 & Estados Unidos & 1.481 \\
\hline 3 & Alemanha & 1.474 \\
\hline 4 & Japão & 823 \\
\hline 5 & Países Baixos & 660 \\
\hline 6 & França & 597 \\
\hline 7 & Coreia do Sul & 555 \\
\hline 8 & Itália & 523 \\
\hline 9 & Rússia & 522 \\
\hline 10 & Bélgica + Luxemburgo & 498 \\
\hline 11 & Reino Unido & 473 \\
\hline 12 & Hong Kong & 459 \\
\hline 13 & Canadá & 452 \\
\hline 14 & Cingapura & 410 \\
\hline 15 & Arábia Saudita & 365 \\
\hline 16 & Taiwan & 350 \\
\hline 17 & México & 308 \\
\hline 18 & Espanha & 297 \\
\hline 19 & Índia & 297 \\
\hline 20 & Emirados Árabes Unidos & 285 \\
\hline 21 & Austrália & 271 \\
\hline 22 & Brasil & 256 \\
\hline 23 & Suíça & 235 \\
\hline 24 & Tailândia & 229 \\
\hline 25 & Malásia & 227 \\
\hline 26 & Indonésia & 201 \\
\hline 27 & Polônia & 187 \\
\hline 28 & Suécia & 187 \\
\hline 29 & Áustria & 179 \\
\hline \multirow[t]{3}{*}{30} & República Tcheca & 162 \\
\hline & Total acima & 14.859 \\
\hline & Total mundial & 18.217 \\
\hline
\end{tabular}

Fonte: SECEX, 2011.

[SYN]THESIS, Rio de Janeiro, vol.8, n 1, 2015, p. 93 - 111 
Tabela 2 - Maiores exportadores mundiais - 2011

\begin{tabular}{|c|c|c|}
\hline \multicolumn{3}{|c|}{ Maiores exportadores mundiais - 2011 (emUS\$ bilhões) } \\
\hline Posição & País & Valor \\
\hline 1 & China & 1.899 \\
\hline 2 & Estados Unidos & 1.481 \\
\hline 3 & Alemanha & 1.474 \\
\hline 4 & Japão & 823 \\
\hline 5 & Países Baixos & 660 \\
\hline 6 & França & 597 \\
\hline 7 & Coreia do Sul & 555 \\
\hline 8 & Itália & 523 \\
\hline 9 & Rússia & 522 \\
\hline 10 & Bélgica + Luxemburgo & 498 \\
\hline 11 & Reino Unido & 473 \\
\hline 12 & Hong Kong & 459 \\
\hline 13 & Canadá & 452 \\
\hline 14 & Cingapura & 410 \\
\hline 15 & Arábia Saudita & 365 \\
\hline 16 & Taiwan & 350 \\
\hline 17 & México & 308 \\
\hline 18 & Espanha & 297 \\
\hline 19 & Índia & 297 \\
\hline 20 & Emirados Árabes Unidos & 285 \\
\hline 21 & Austrália & 271 \\
\hline 22 & Brasil & 256 \\
\hline 23 & Suíça & 235 \\
\hline 24 & Tailândia & 229 \\
\hline 25 & Malásia & 227 \\
\hline 26 & Indonésia & 201 \\
\hline 27 & Polônia & 187 \\
\hline 28 & Suécia & 187 \\
\hline 29 & Áustria & 179 \\
\hline \multirow[t]{3}{*}{30} & República Tcheca & 162 \\
\hline & Total acima & 14.859 \\
\hline & Total mundial & 18.217 \\
\hline
\end{tabular}

Fonte: SECEX, 2011.

Seguindo ainda na caracterização do comércio brasileiro, observa-se a presença da Ásia como maior mercado fornecedor do país em 2011, respondendo por aproximadamente $31 \%$ do fluxo comercial, logo seguida pela União Europeia (20,5\%) e América Latina e Caribe (16,7\%). Do mesmo modo, quando se trata dos principais mercados de destino das exportações brasileiras, no mesmo período, aparecem Ásia, 
América Latina e Caribe e União Europeia, 22,4\% e 20,7\%. Esses dados podem ser confirmados respondendo cada uma, respectivamente, por 30\%, por meio dos Gráficos 1 e 2 .

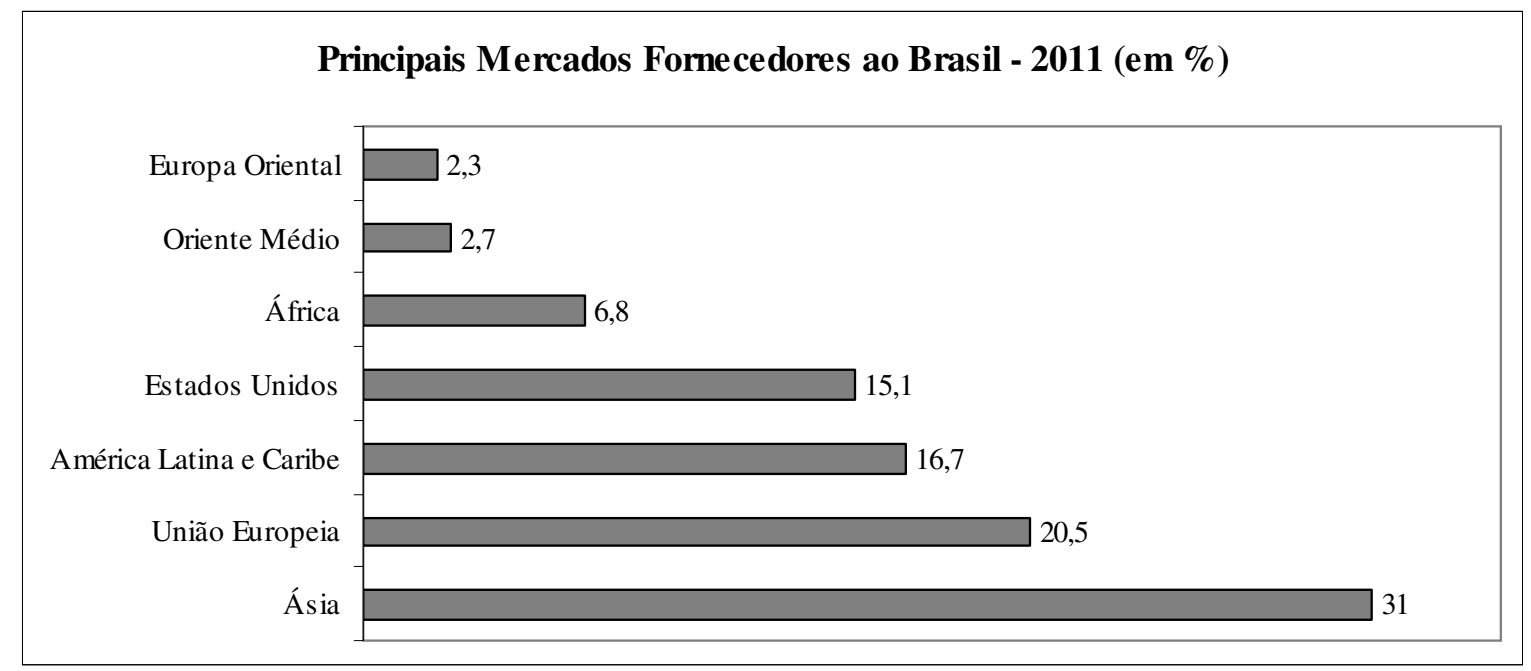

Gráfico 1 - Principais Mercados Fornecedores ao Brasil - 2011

Fonte: SECEX, 2012.

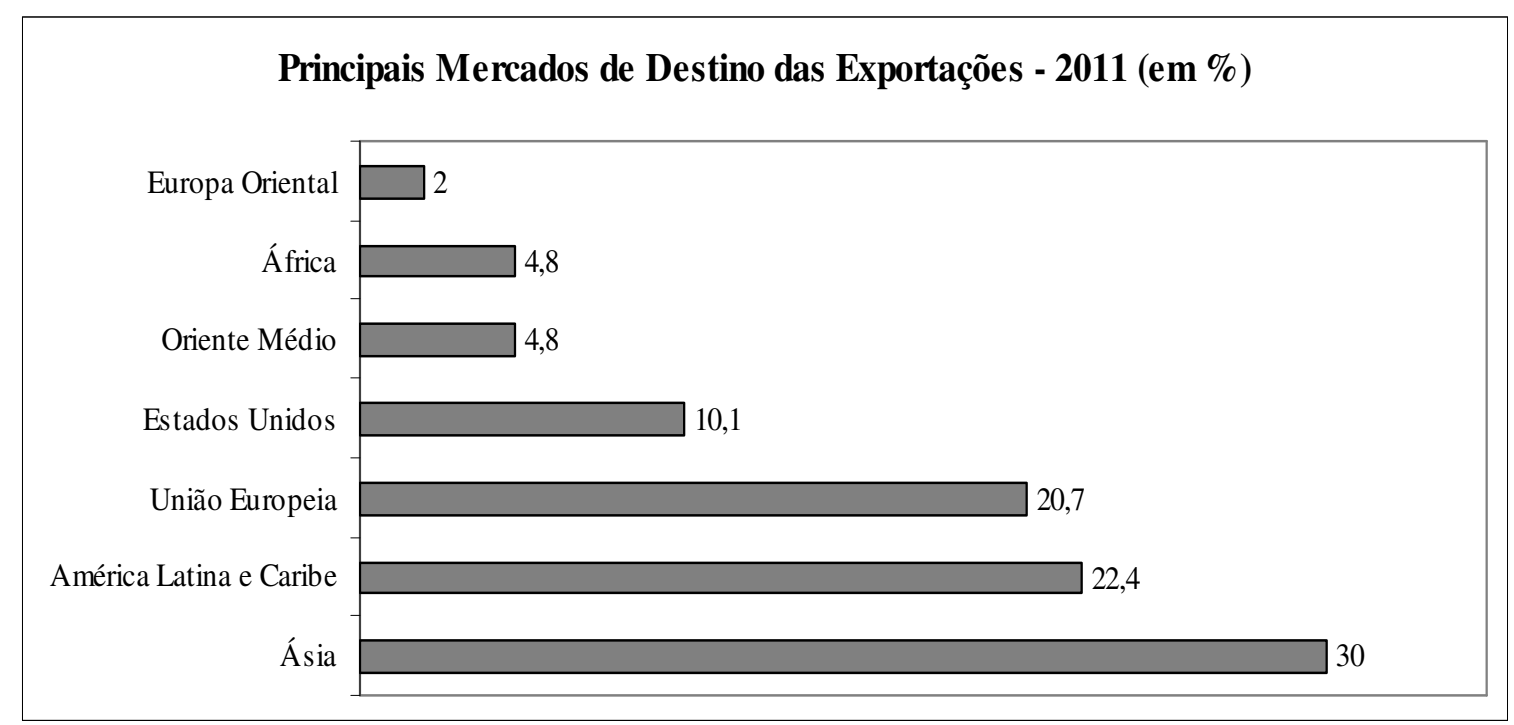

Gráfico 2 - Principais Mercados de Destino das Exportações - 2011

Fonte: SECEX, 2012.

Ao se iniciar uma análise mais profunda a respeito da relação comercial do Brasil com o mundo, partindo da visualização por país, é verificada forte presença da Argentina, $3^{\text {a }}$ economia mais desenvolvida da América Latina (superada apenas por Brasil e México), tanto na pauta das importações quanto na das exportações, razão pela qual o relacionamento com esse país deve ser mais detalhado no que tange a seus processos de internacionalização. Em 2011, o mercado argentino figurou em terceiro lugar em ambos os fluxos, como mostram as Tabelas 3 e 4 . 
Tabela 3 - Principais Países Fornecedores ao Brasil - 2011

\begin{tabular}{|c|c|c|}
\hline \multicolumn{3}{|c|}{ Principais Países Fornecedores ao Brasil - 2011 (em \%) } \\
\hline Posição & País & Participação \\
\hline 1 & Estados Unidos & 15 \\
\hline 2 & China & 14,5 \\
\hline 3 & Argentina & 7,5 \\
\hline 4 & Alemanha & 6,7 \\
\hline 5 & Coreia do Sul & 4,5 \\
\hline
\end{tabular}

Fonte: SECEX, 2012.

Tabela 4 - Principais Países Compradores do Brasil - 2011

\begin{tabular}{c|c|c}
\hline \multicolumn{3}{c}{ Principais Países Compradores do Brasil - 2011 (em \%) } \\
\cline { 2 - 3 } Posição & País & Participação \\
\hline 1 & China & 17,3 \\
\hline 2 & Estados Unidos & 10,1 \\
\hline 3 & Argentina & 8,9 \\
\hline 4 & Países Baixos & 5,3 \\
\hline 5 & Japão & 3,7 \\
\hline
\end{tabular}

Fonte: SECEX, 2012.

Em virtude da forte participação argentina na dinâmica econômica do Brasil, um estudo da relação entre as duas nações é imprescindível para avaliar fluxos, origens e processos, e se aproximar da realidade de todo o Cone Sul.

Do mesmo modo, a relação entre Brasil e Argentina não pode se basear na premissa de ser entendida apenas bilateralmente, mas deve ser encarada na perspectiva mais ampla das relações mundiais de poder (MONIZ BANDEIRA, 2010).

Segundo Moniz Bandeira (2010), o tipo de pensamento que leva em consideração as relações de um país com os demais de forma apenas individual é artificial e falso, e frequentemente resulta em sérios desentendimentos. Para tanto, busca-se ancorar a relação bilateral Brasil-Argentina, foco deste trabalho, às oscilações inerentes aos movimentos mundiais. É o que se objetiva fazer, no correr dessas linhas, ao analisar as características históricas dos dois países em questão e, em alguma medida, associá-las à dinâmica internacional.

\section{A Relação comercial Brasil-Argentina}

\subsection{Considerações sobre o Mercosul}

Não obstante o peso relativo e a importância fundamental para a América Latina, até o início dos anos oitenta, a relação entre Brasil e Argentina sempre foi marcada pela desconfiança mútua. A partir, porém, da Guerra das Malvinas em 1982, um novo período de relação entre os dois países se inaugurou, consequência direta do processo de redemocratização em ambos e da nova dinâmica do mercado mundial. Em 1985, os presidentes Sarney e Alfonsín assinaram a Declaração do Iguaçu, que constava de 19 protocolos de cooperação econômica, com vistas a uma futura integração regional, que veio a se concretizar em 1991, por meio da assinatura do Tratado de Assunção e criação do Mercado Comum do Sul (MERCOSUL). 
O Mercosul foi criado em 26 de março de 1991, através da assinatura do já referido tratado pelos seguintes países: Argentina, Brasil, Paraguai e Uruguai. A Venezuela encontra-se em processo de adesão, enquanto Bolívia, Chile, Peru, Colômbia e Equador permanecem com o status de estados associados.

A integração regional, viabilizada por meio do referido tratado, consiste em uma união aduaneira imperfeita. Enquanto uma união aduaneira é caracterizada pela fixação de uma Tarifa Externa Comum (TEC), ou seja, uma tarifa a ser aplicada por todos os sócios ao comércio de bens com terceiros mercados, a tarifa praticada pelos membros do Mercosul exclui diversos produtos.

A TEC é sempre um dos principais pontos de discussão nos processos de integração, pois a abertura comercial entre os estados-membros pode inviabilizar segmentos importantes para os países mais vulneráveis. No caso do Mercosul, a lista de exceção de certos produtos ocorre com o intuito de permitir que a economia dos países-membros tenha tempo de adaptar suas novas estruturas de custos dentro de um mercado internacional competitivo. Aliás, essa flexibilidade característica do Mercado Comum do Cone Sul foi o que permitiu sua sobrevivência em períodos de crises internas e externas nos países do bloco. Averbug (1998) explica que, nesse caso, as tarifas elevadas são cobradas sobre produtos mais sensíveis à concorrência externa, ao passo que taxas reduzidas são aplicadas sobre certos bens estratégicos como, por exemplo, bens de capital usados na fabricação de produtos de exportação, bens não produzidos no mercado interno etc.

$\mathrm{O}$ acordo, logo em sua fase inicial, intensificou o fluxo comercial e, consequentemente, a interdependência econômica entre os países, e mais precisamente entre os dois tratados neste estudo, graças ao significativo grau de liberalização de barreiras tarifárias e a proximidade geográfica. Alternou períodos de avanços com outros de certa paralisia, de acordo com as conjunturas econômicas e contextos políticos, que serão explicitadas no decorrer das linhas referentes ao quantum do comércio entre Brasil e Argentina (Item 3.2.2). Hoje, importadores e exportadores desses países podem realizar transações com suas respectivas moedas por meio do Sistema de Pagamentos em Moeda Local (SML), além de poder contar com facilidades no que diz respeito à livre circulação de bens, serviços e fatores produtivos, ao estabelecimento da TEC, à adoção de uma política comercial comum, à coordenação de políticas macroeconômicas e setoriais, e à harmonização de legislações nas áreas pertinentes.

O SML citado acima é um sistema de pagamentos informatizado que permite a remetentes e destinatários, nos países que integram o sistema, fazer e receber pagamentos referentes a transações comerciais em suas respectivas moedas, aumentando, dessa forma, o nível de acesso dos pequenos e médios agentes, possibilitando o comércio exterior em moedas locais e reduzindo custos de transação. Em março de 2011, o Tratado de Assunção celebrou 20 anos de sua assinatura em 1991. Sua trajetória permitiu avanços tanto no plano econômico quanto político, desempenhando importante papel na inserção internacional dos países integrantes do acordo. $\mathrm{O}$ papel econômico, a despeito dos percalços provocados por crises financeiras, é significativo: desde a sua criação, o Mercosul tem sido um dos principais destinos das exportações do Brasil e um dos seus principais fornecedores. Vale ressaltar que o comércio entre os parceiros regionais se elevou de US $\$ 4,5$ bilhões em 1991 para US\$ 45 bilhões em 2010. No plano político, o acordo foi importante para a superação de diferenças e para que o Brasil se transformasse em um líder respeitado regionalmente. A diminuição dos entraves ao comércio internacional vem para fortalecer ainda mais a dinâmica desse bloco.

Os aspectos positivos da integração econômica podem ser constatados por meio do gráfico abaixo, que evidencia o fluxo comercial brasileiro com o Mercosul, desde 1991, ano da assinatura do Tratado de Assunção, até dezembro de 2011. 


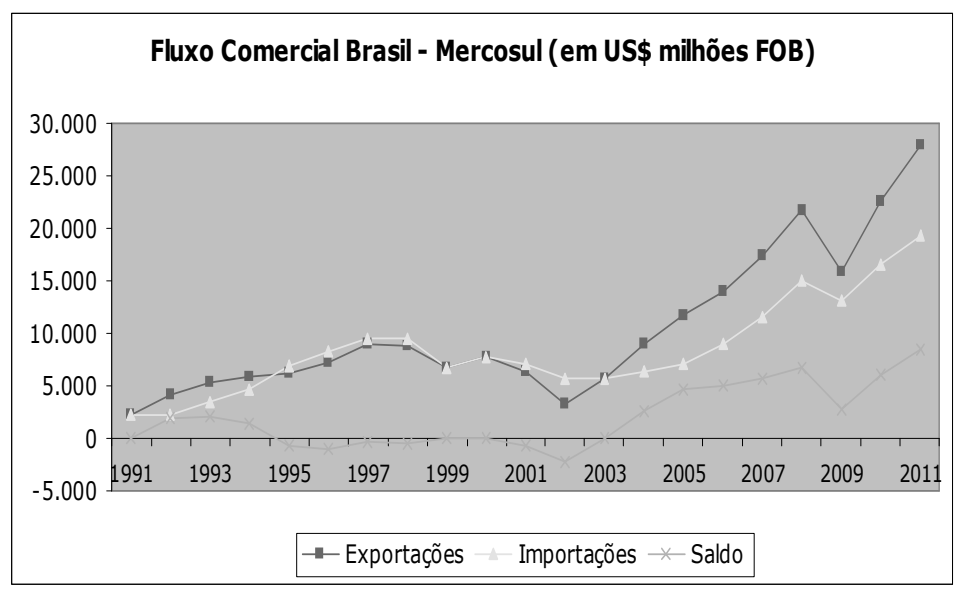

Gráfico 3 - Fluxo Comercial Brasil - Mercosul

Fonte: SECEX, 2012

\subsection{A anÁlISE COMERCIAL BRASIL-ARgentina}

Partindo da ideia já citada da relevância da relação comercial Brasil - Argentina, uma análise desta tem espaço aqui. Apenas em 2011, o comércio brasileiro com o mercado argentino registrou US\$ 39,6 bilhões, com ampliação de $20,2 \%$ sobre o mesmo período de 2010, quando atingiu US\$32,9 bilhões. As exportações encerraram o período com valor de US \$ 22,7 bilhões e as importações de US\$ 16,9 bilhões, resultados igualmente expressivos. $\mathrm{O}$ saldo comercial atingiu US $\$ 5,8$ bilhões em 2011, significando ampliação de 41,9\% sobre o mesmo período de 2010, de US\$ 4,1 bilhões, motivado por um maior aumento das exportações em relação às importações.

Dados recentes apontam para um aumento ainda maior nesse comércio, que atingiu níveis recordes em novembro de 2011, com um volume de US\$ 3,7 bilhões, representando um aumento de 19,8\% em comparação com igual mês de 2010.

As informações da balança comercial de Brasil e Argentina serão analisadas de acordo com o referencial teórico das quatro questões básicas que determinam o comércio internacional de bens: direção do comércio, quantum, padrão de comércio e termos de troca (GONÇALVES, 2005).

\subsubsection{DIREÇÃo DO COMÉRCIO}

A direção do comércio é a distribuição geográfica dos fluxos de comércio exterior, ou seja, é a questão da origem das importações e do destino das exportações. No presente trabalho, por se tratar da relação bilateral Brasil-Argentina, esse fluxo pode ser facilmente identificado.

\subsubsection{QUANTUM}

O tema do quantum trata da quantidade (mensurada de diversas formas) dos produtos comercializados internacionalmente por cada país. Aqui, são utilizados como medidas os valores monetários em US \$ através da balança comercial entre os dois países. Além disso, eles são considerados em termos FOB (do inglês free on board), ou seja, o valor das exportações e importações exclui os gastos com fretes e seguros.

A Tabela 5 apresentada a seguir mostra os dados dessa balança, o saldo e a corrente de comércio para o período de 1991, ano de criação do Mercosul, até dezembro de 2011. Vale ressaltar que, por se tratar de uma relação bilateral, o valor das exportações brasileiras para a Argentina equivale ao valor das importações argentinas no mercado brasileiro. O mesmo ocorre no caso das importações, ou seja, o valor importado pelo Brasil do mercado argentino é equivalente ao valor do que a Argentina exporta para o Brasil. 
Tabela 5 - Balança Comercial Brasil - Argentina

\begin{tabular}{c|c|c|c|c}
\hline \multicolumn{6}{c}{ Balança Comercial Brasil - Argentina (em US\$ FOB) } \\
\hline Ano & Exportação & Importação & Saldo & Corrente de comércio \\
\hline 1991 & 1.476 .170 .289 & 1.609 .295 .051 & -133.124 .762 & 3.085 .465 .340 \\
\hline 1992 & 3.039 .983 .798 & 1.731 .625 .482 & 1.308 .358 .316 & 4.771 .609 .280 \\
\hline 1993 & 3.658 .779 .257 & 2.717 .266 .437 & 941.512 .820 & 6.376 .045 .694 \\
\hline 1994 & 4.135 .864 .352 & 3.661 .966 .005 & 473.898 .347 & 7.797 .830 .357 \\
\hline 1995 & 4.041 .135 .877 & 5.591 .392 .742 & -1.550 .256 .865 & 9.632 .528 .619 \\
\hline 1996 & 5.170 .031 .615 & 6.805 .466 .613 & -1.635 .434 .998 & 11.975 .498 .228 \\
\hline 1997 & 6.769 .401 .758 & 7.941 .275 .826 & -1.171 .874 .068 & 14.710 .677 .584 \\
\hline 1998 & 6.748 .203 .941 & 8.023 .468 .113 & -1.275 .264 .172 & 14.771 .672 .054 \\
\hline 1999 & 5.364 .140 .489 & 5.812 .211 .301 & -448.070 .812 & 11.176 .351 .790 \\
\hline 2000 & 6.237 .684 .373 & 6.843 .231 .619 & -605.547 .246 & 13.080 .915 .992 \\
\hline 2001 & 5.009 .810 .224 & 6.206 .537 .463 & -1.196 .727 .239 & 11.216 .347 .687 \\
\hline 2002 & 2.346 .508 .274 & 4.743 .785 .116 & -2.397 .276 .842 & 7.090 .293 .390 \\
\hline 2003 & 4.569 .767 .654 & 4.672 .610 .523 & -102.842 .869 & 9.242 .378 .177 \\
\hline 2004 & 7.390 .967 .394 & 5.569 .811 .952 & 1.821 .155 .442 & 12.960 .779 .346 \\
\hline 2005 & 9.930 .152 .936 & 6.241 .110 .029 & 3.689 .042 .907 & 16.171 .262 .945 \\
\hline 2006 & 11.739 .591 .939 & 8.053 .262 .647 & 3.686 .329 .292 & 19.792 .854 .586 \\
\hline 2007 & 14.416 .945 .588 & 10.404 .245 .932 & 4.012 .699 .656 & 24.821 .191 .520 \\
\hline 2008 & 17.605 .620 .920 & 13.258 .441 .511 & 4.347 .179 .409 & 30.864 .062 .431 \\
\hline 2009 & 12.784 .966 .502 & 11.281 .656 .656 & 1.503 .309 .846 & 24.066 .623 .158 \\
\hline 2010 & 18.522 .520 .610 & 14.434 .186 .779 & 4.088 .333 .831 & 32.956 .707 .389 \\
\hline 2011 & 22.709 .344 .431 & 16.906 .099 .483 & 5.803 .244 .948 & 39.615 .443 .914 \\
\hline
\end{tabular}

Fonte: Alice Web - Ministério do Desenvolvimento Indústria e Comércio Exterior, 2012.

Para a construção da avaliação do comércio bilateral Brasil-Argentina, uma breve análise histórica deve ser apresentada em relação a esse fluxo. Se o intercâmbio comercial entre os dois países após a constituição do Mercosul fosse dividido em fases, chegar-se-ia a três etapas distintas:

A primeira etapa, compreendida entre $1991 \mathrm{e}$ 1998, pode ser considerada positiva, pois a relação Brasil-Argentina se estreita com a constituição do Mercosul e por meio da redução sistemática das tarifas aduaneiras entre os dois países - excluindo certos produtos - a participação das mercadorias brasileiras e argentinas em direção ao outro país se torna mais expressiva para ambos. A participação argentina nas exportações brasileiras, que inicia 1991 respondendo por $4,67 \%$ do total exportado pelo Brasil, chega em 1998 com a porcentagem de $13,2 \%$ do total. O mesmo ocorre com as importações brasileiras oriundas do país vizinho, que de $7,65 \%$ passam a $13,89 \%$ do total.

$\mathrm{Na}$ segunda etapa, que compreende os anos de 1998 a 2002, essa relação pode ser considerada negativa, pois a América Latina é afetada por uma grande crise internacional, culminando na adoção brasileira do câmbio flutuante frente ao câmbio fixo da Argentina (vigente desde 1991), que se inviabilizou na própria Argentina e desestabilizou a dimensão macroeconômica da integração. Mesmo nesse período de crise, os produtos brasileiros entraram mais no 
mercado argentino, chegando ao ponto de que em 2002 mais de 1/4 das importações mundiais totais da Argentina fosse proveniente do Brasil. A participação argentina nas exportações brasileiras, que respondia por $13,2 \%$ do total exportado pelo Brasil, despenca em 2002 para 3,88\% do total. A mesma situação ocorre com as importações brasileiras oriundas do país vizinho que, embora em menor proporção, de $13,89 \%$ passam a $10,04 \%$ do total no mesmo período.

Na terceira e última etapa, que se estende de 2002 até os dias atuais, há a retomada do crescimento, através da adoção de um novo perfil comercial extrabloco. Após o ano de 2002, a América Latina começa a se recuperar das crises econômicas do México, da Ásia e da Rússia, que assolaram a região na década de 1990. Com isso, o fluxo comercial BrasilArgentina voltou a crescer fortemente, sinalizando a retomada da integração comercial. Esse novo fôlego na relação comercial tem crescimentos sucessivos, e seu ápice em 2008, quando as exportações brasileiras em direção ao mercado argentino atingem a cifra de US\$ 17,6 bilhões. Em 2009, esse fluxo é abalado em virtude da crise deflagrada nos Estados Unidos ao final de 2008. As exportações brasileiras destinadas ao comércio com a Argentina caem $27,4 \%$, enquanto as importações argentinas no mercado do Brasil caem 14,9\% em relação a 2008. Esse comércio já é restabelecido em 2010 e apresenta tendência crescente, apesar de algumas barreiras protecionistas impostas pela Argentina a importações de produtos brasileiros em setores como o de calçados, têxteis e vestuário, autopeças (freios, embreagens, baterias), tornos, móveis de madeira, linha branca (geladeiras, TVs, entre outros) e celulose e papel (MACADAR, 2008).

A evolução desses fluxos entre os dois países pode ser vista no Gráfico 4, correspondente ao período de 1991 até fins de 2011.

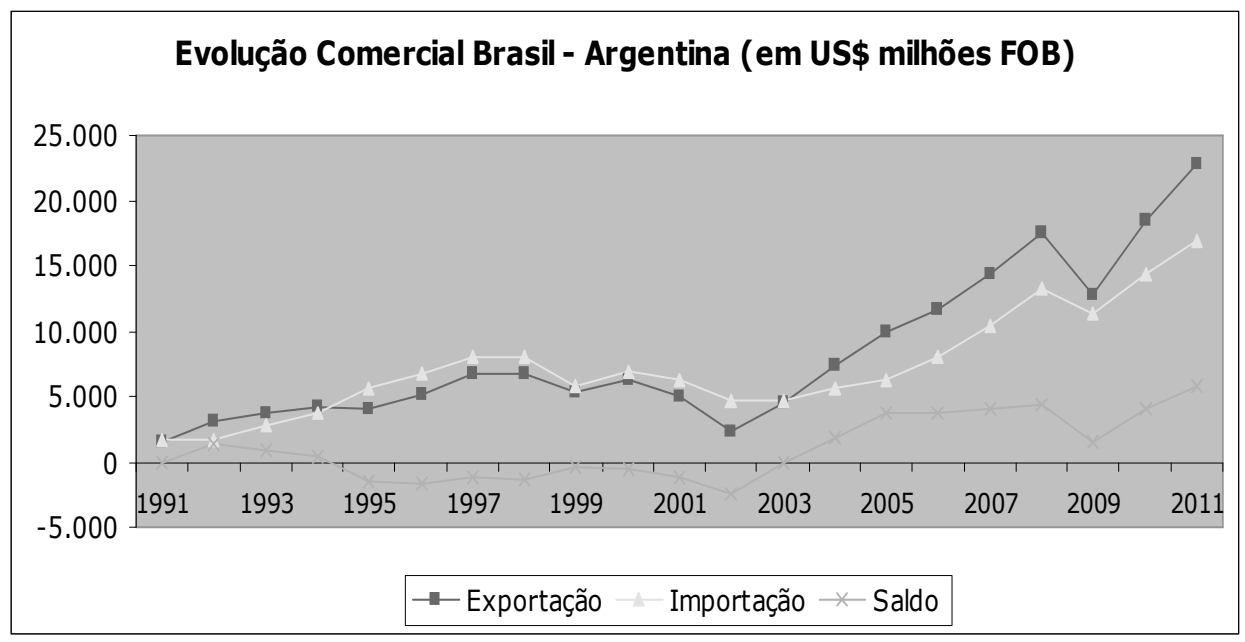

Gráfico 4 - Evolução Comercial Brasil - Argentina

Fonte: Alice Web - Ministério do Desenvolvimento Indústria e Comércio Exterior, 2012.

\subsubsection{PADRÃo de COMÉRCIO}

O padrão de comércio (também conhecido como padrão de vantagem comparativa) refere-se à composição ou estrutura de exportação ou importação do país, ou seja, quais produtos são exportados e quais produtos são importados.

Nessa parte, serão localizados os segmentos mais importantes, assim como as empresas que têm maior participação no comércio no entre os dois países.

Segundo dados da SECEX, na lista dos principais produtos brasileiros exportados para a Argentina, itens do setor automotivo sempre apresentaram papel de destaque. Isso se deveu principalmente porque em 2000 foi protocolado um acordo bilateral para esta área. Outro setor, porém, de relevância foi o de minério de ferro que de um montante de US\$ 80,9 
milhões, ou 0,63\% do total exportado para a Argentina em 2009, passou a responder por uma cifra de US\$ 1,35 bilhão ou 5,96\% do total em 2011 .
A tabela abaixo mostra os cinco principais produtos brasileiros exportados para o mercado argentino, durante o período que compreende os anos entre 2006 e 2011.

Tabela 6 - Os cinco principais produtos exportados para a Argentina

\begin{tabular}{|c|c|c|c|c|c|c|}
\hline \multicolumn{7}{|c|}{ Os cinco principa is produtos exportados para a Argentina e seu peso relativo } \\
\hline Ano & \multicolumn{5}{|c|}{ Produtos } & $\begin{array}{l}\text { Peso } \\
\text { rela- }\end{array}$ \\
\hline 2006 & $\begin{array}{c}\text { Automóveis c/ } \\
\text { motor explosão, } \\
1500<\mathrm{cm}^{3}<3000 \\
\text { até } 6 \text { passag. }\end{array}$ & $\begin{array}{c}\text { Outros } \\
\text { automóveis c/ } \\
\text { motor diesel, p/ } \\
\text { carga }<=5 \mathrm{~T}\end{array}$ & "Fuel oil" & $\begin{array}{c}\text { Minérios de } \\
\text { ferro } \\
\text { aglomerados e } \\
\text { seus } \\
\text { concentrados }\end{array}$ & $\begin{array}{c}\text { Chassis com } \\
\text { motor diesel e } \\
\text { cabina, } \\
5 \mathrm{~T}<\mathrm{carga}<=20 \\
\mathrm{~T}\end{array}$ & $17,33 \%$ \\
\hline 2007 & $\begin{array}{c}\text { Automóveis c/ } \\
\text { motor explosão, } \\
1500<\mathrm{cm}^{3}<3000 \\
\text { até } 6 \text { passag. }\end{array}$ & $\begin{array}{c}\text { Terminais } \\
\text { portáteis de } \\
\text { telefon ia celular }\end{array}$ & $\begin{array}{c}\text { Automóveis cl } \\
\text { motor explosão, } \\
1000<\mathrm{cm}^{3}<1500 \\
\text { até } 6 \text { passag. }\end{array}$ & "Fuel oil" & $\begin{array}{l}\text { Outros } \\
\text { automóveis c/ } \\
\text { motor diesel, } \\
\text { p/ carga }<=5 \mathrm{~T}\end{array}$ & $19,91 \%$ \\
\hline 2008 & $\begin{array}{c}\text { Automóveis c/ } \\
\text { motor explosão, } \\
1500<\mathrm{cm}^{3}<3000 \\
\text { até } 6 \text { passag. }\end{array}$ & $\begin{array}{c}\text { Terminais } \\
\text { portáteis de } \\
\text { telefon ia celular }\end{array}$ & "Fuel oil" & $\begin{array}{c}\text { Automóveis cl } \\
\text { motor explosão, } \\
1000<\mathrm{cm}^{3}<1500 \\
\text { até } 6 \text { passag. }\end{array}$ & $\begin{array}{c}\text { Minérios de } \\
\text { fer ro } \\
\text { aglomerados e } \\
\text { seus } \\
\text { concentrados }\end{array}$ & $22,60 \%$ \\
\hline 2009 & $\begin{array}{c}\text { Automóveis c/ } \\
\text { motor explosão, } \\
1500<\mathrm{cm}^{3}<3000 \\
\text { até } 6 \text { passag. }\end{array}$ & Energ ia elétrica & $\begin{array}{c}\text { Terminais } \\
\text { portáte is de } \\
\text { telefonia celular }\end{array}$ & $\begin{array}{c}\text { Automóveis cl } \\
\text { motor explosão, } \\
1000<\mathrm{cm}^{3}<1500 \\
\text { até } 6 \text { passag. }\end{array}$ & $\begin{array}{l}\text { Outras partes } \\
\text { e acess. de } \\
\text { carrocerias p/ } \\
\text { automóveis }\end{array}$ & $28,19 \%$ \\
\hline 2010 & $\begin{array}{c}\text { Automóveis c/ } \\
\text { motor explosão, } \\
1500<\mathrm{cm}^{3}<3000 \\
\text { até } 6 \text { passag. }\end{array}$ & $\begin{array}{c}\text { Automóveis c/ } \\
\text { motor explosão, } \\
1000<\mathrm{cm}^{3}<1500 \\
\text { até } 6 \text { passag. }\end{array}$ & $\begin{array}{c}\text { Minérios de } \\
\text { ferro } \\
\text { aglomerados e } \\
\text { seu s } \\
\text { concentrados }\end{array}$ & $\begin{array}{l}\text { Terminais } \\
\text { portáteis de } \\
\text { telefonia celular }\end{array}$ & $\begin{array}{l}\text { Outros } \\
\text { automóveis c/ } \\
\text { motor diesel, } \\
\text { p/ carga }<=5 \mathrm{~T}\end{array}$ & $22 \%$ \\
\hline 2011 & $\begin{array}{c}\text { Automóveis c/ } \\
\text { motor explosão, } \\
1500<\mathrm{cm}^{3}<3000 \\
\text { até } 6 \text { passag. }\end{array}$ & $\begin{array}{c}\text { Automóveis c/ } \\
\text { motor explosão, } \\
1000<\mathrm{cm}^{3}<1500 \\
\text { até } 6 \text { passag. }\end{array}$ & $\begin{array}{l}\text { Minérios de } \\
\text { ferro } \\
\text { aglomerados e } \\
\text { seus } \\
\text { concentrados }\end{array}$ & $\begin{array}{l}\text { Minérios de } \\
\text { ferro não } \\
\text { aglomerados e } \\
\text { seus } \\
\text { concentrados }\end{array}$ & "Fuel oil" & $\begin{array}{c}23,88 \\
\%\end{array}$ \\
\hline
\end{tabular}

Fonte: SECEX, 2012.

A partir da lista dos principais produtos importados pelo Brasil, oriundos do mercado argentino, nota-se que o fluxo de importação brasileiro é mais concentrado em determinados setores do que a contrapartida argentina. Produtos como o trigo e petroquímicos sempre contribuíram com uma porção relevante desse fluxo, mas vêm perdendo espaço para o setor automotivo. O trigo, que em 2006 correspondia a $11,3 \%$ do total importado no mercado argentino pelo Brasil, chegou em 2011 respondendo por $8,76 \%$. O mesmo ocorreu com a nafta da indústria petroquímica, que passou de $9,74 \%$ para $5,79 \%$ no mesmo período. Por outro lado, o setor automotivo presente na pauta apresenta tendência crescente. 
Exemplo disso são os automóveis com motor a explosão, $1500<\mathrm{cm}^{3}<3000$, de até seis passageiros, que em 2011 fizeram com que o Brasil despendesse US\$1,7 bilhão, enquanto em 2006 o montante era de US\$ 594 milhões, um crescimento de, aproximadamente, $186,2 \%$.

A Tabela 7 exibe os cinco principais produtos importados pelo Brasil do mercado argentino, no período que compreende os anos entre 2006 e 2011.

Tabela 7 - Os cinco principais produtos importados da Argentina e seu peso relativo

\begin{tabular}{|c|c|c|c|c|c|c|}
\hline \multicolumn{7}{|c|}{ Os cinco principais produtos importados da Argentina e seu peso re lativo } \\
\hline \multirow{2}{*}{$\begin{array}{l}\text { A no } \\
2006\end{array}$} & \multicolumn{5}{|c|}{ Produtos } & \multirow{2}{*}{$\begin{array}{c}\text { Peso relativo } \\
37,24 \%\end{array}$} \\
\hline & $\begin{array}{c}\text { Trigo (exc. trigo } \\
\text { duro ou p/ } \\
\text { semeadura) e trigo } \\
\text { c/ centeio }\end{array}$ & $\begin{array}{c}\text { Naf ta para } \\
\text { petroquímica }\end{array}$ & $\begin{array}{c}\text { Autom óveis com } \\
\text { m otor explosão, } \\
1500<\mathrm{cm}^{3}<=3000, \\
\text { a té } 6 \text { passag. }\end{array}$ & $\begin{array}{c}\text { Outros } \\
\text { autom óve is c/ } \\
\text { motor diese } 1, \mathrm{p} / \\
\text { carga } \operatorname{ar}=5 \mathrm{~T}\end{array}$ & $\begin{array}{l}\text { Butano } \\
\text { lique feito }\end{array}$ & \\
\hline 2007 & $\begin{array}{l}\text { Trigo (exc. trigo } \\
\text { duro ou p/ } \\
\text { semeadura) e trigo } \\
\text { c/ centeio }\end{array}$ & $\begin{array}{c}\text { Naf ta para } \\
\text { petroquímica }\end{array}$ & $\begin{array}{c}\text { Autom óveis com } \\
\text { motor explosão, } \\
1500<\mathrm{cm}^{3}<=3000 \\
\text { a té } 6 \text { passag. }\end{array}$ & $\begin{array}{l}\text { Outros } \\
\text { autom óve is c/ } \\
\text { motor diese } 1, \mathrm{p} / \\
\text { carga }<=5 \mathrm{~T}\end{array}$ & $\begin{array}{c}\text { Automóveis } \\
\text { c/ motor } \\
\text { explosão, } \\
\text { C IL }<=1000 \mathrm{~cm}^{3}\end{array}$ & $41,01 \%$ \\
\hline 2008 & $\begin{array}{c}\text { A utom óveis com } \\
\text { motor explosão, } \\
1500<\mathrm{cm}^{3}<=3000 \\
\text { até } 6 \text { passag. }\end{array}$ & $\begin{array}{c}\text { Nafta para } \\
\text { petroquímica }\end{array}$ & $\begin{array}{l}\text { Trigo (exc. trigo } \\
\text { duro ou p/ } \\
\text { sem eadura) e } \\
\text { trig oc/ centeio }\end{array}$ & $\begin{array}{l}\text { Outros } \\
\text { autom óve is c/ } \\
\text { motor diese } 1, \mathrm{p} / \\
\text { carga }<=5 \mathrm{~T}\end{array}$ & $\begin{array}{c}\text { A utom óveis } \\
\text { c/ m otor } \\
\text { explosã o, } \\
\text { C IL }<=1000 \mathrm{~cm}^{3}\end{array}$ & $39,56 \%$ \\
\hline 2009 & $\begin{array}{c}\text { A utom óveis com } \\
\text { motor explosão, } \\
1500<\mathrm{cm}^{3}<=3000 \\
\text { até } 6 \text { passag. }\end{array}$ & $\begin{array}{l}\text { Outros } \\
\text { automóveis c/ } \\
\text { motor diesel, } \\
\text { p/carga }<=5 \mathrm{~T}\end{array}$ & $\begin{array}{c}\text { Trigo (exc. trigo } \\
\text { duroou p/ } \\
\text { semeadura)e trigo } \\
\text { c/ centeio }\end{array}$ & $\begin{array}{l}\text { Autom óveis c/ } \\
\text { motor explosão, } \\
\text { CIL }<=1000 \mathrm{~cm}^{3}\end{array}$ & $\begin{array}{l}\text { Nafta para } \\
\text { petroquím ic a }\end{array}$ & $37,88 \%$ \\
\hline 2010 & $\begin{array}{c}\text { Autom óveis com } \\
\text { motor explosão, } \\
1500<\mathrm{cm}^{3}<=3000 \\
\text { atế } 6 \text { passag. }\end{array}$ & $\begin{array}{l}\text { Outros } \\
\text { automóveis c/ } \\
\text { motor diesel, } \\
\text { p/carga }<=5 \mathrm{~T}\end{array}$ & $\begin{array}{l}\text { A utomóveis } \mathrm{c} / \\
\mathrm{m} \text { otor explos a } \\
1000<\mathrm{cm}^{3}<1500 \\
\text { a té } 6 \text { passag. }\end{array}$ & $\begin{array}{l}\text { Autom óveis c/ } \\
\text { motor explosão, } \\
\text { CIL }<=1000 \mathrm{~cm}^{3}\end{array}$ & $\begin{array}{c}\text { Trigo (exc. } \\
\text { trigo duro ou p/ } \\
\text { semeadura) e } \\
\text { trigoc/centeio }\end{array}$ & $40,10 \%$ \\
\hline 2011 & $\begin{array}{c}\text { Autom óveis com } \\
\text { motor explosão, } \\
1500<\mathrm{cm}^{3}<=3000, \\
\text { até } 6 \text { passag. }\end{array}$ & $\begin{array}{l}\text { Outros } \\
\text { automóveis c/ } \\
\text { motor diesel, } \\
\text { p/carga }<=5 \mathrm{~T}\end{array}$ & $\begin{array}{c}\text { Trigo (exc. trigo } \\
\text { duroou p/ } \\
\text { semeadura) e trigo } \\
\text { c/ centeio }\end{array}$ & $\begin{array}{c}\text { Autom óveis c/ } \\
\text { motor explosão, } \\
1000<\mathrm{cm}^{3}<1500 \\
\text { a té } 6 \text { passag. }\end{array}$ & $\begin{array}{c}\text { Nafta para } \\
\text { pe troquím ic a }\end{array}$ & $42,54 \%$ \\
\hline
\end{tabular}

Fonte: SECEX, 2012.

No que tange às empresas de presença predominante na relação brasileira com o mundo, e nesta relação bilateral em particular, percebe-se que os fluxos são dominados por grandes empresas, em especial as empresas transnacionais (ETs), que ao longo dos anos foram aumentando exponencialmente suas fatias de mercado, mostrando um comércio cada vez mais aquecido e protagonizado por grandes empresas. As transnacionais são grandes empresas que possuem matriz em um país, mas atuam em outros, através de suas filiais, em busca de mercado consumidor, energia, matéria-prima e mão de obra baratas. Na realidade brasileira, as mesmas começaram a ganhar destaque a partir da década de 1950, quando o país acelerou seu processo de industrialização, iniciado na década de 1930, em sua fase estimulada.

No comércio internacional dominado pelas transnacionais, a lógica é a fragmentação das cadeias produtivas, fazendo com que o comércio intraindústrias cresça consideravelmente, estando cada vez mais presente na economia global devido à 
intensificação do processo de internacionalização das grandes corporações. Esse comércio ocorre entre a matriz e suas filiais e/ou entre as filiais de uma mesma empresa transnacional. O melhor exemplo é o caso do segmento automotivo, onde algumas ETs do oligopólio internacional têm produção na Argentina e no Brasil. O destaque é a FIAT e suas unidades em Betim (Minas Gerais) e Córdoba (Argentina), assim como das grandes ETs do agronegócio (Bunge, Cargil, Danone, Monsanto, Parmalat).
A Tabela 8 apresenta em ordem decrescente as empresas no Brasil que mais exportaram para a Argentina, em valores acima de US\$ 50 milhões, no período de 2007 até 2011. As empresas que possuem mais de uma unidade de produção presente no ranking foram listadas com a respectiva cidade e estado onde estão instaladas. No caso da Fiat, com duas unidades produtivas em Betim (Minas Gerais), as mesmas foram apresentadas com os respectivos bairros onde se localizam.

Tabela 8 - Empresas no Brasil que mais exportaram para a Argentina

\begin{tabular}{|c|c|c|c|c|}
\hline \multirow[t]{2}{*}{ Empresas no } & \multicolumn{4}{|c|}{ Brasil que mais exportaram para a A gentina (acima de U $S \$ 50 \mathrm{~m}$ ilh ós) } \\
\hline & 2008 & 2009 & 2010 & 2011 \\
\hline $\begin{array}{c}\text { Fiat } \\
(\text { Betim-M G / } \\
\text { Paulo Camilo) }\end{array}$ & $\begin{array}{c}\text { Fiat } \\
\text { (Betim-MG } \\
\text { Paulo Camilo) }\end{array}$ & $\mathrm{C}$ ie $\mathrm{n}$ & $\begin{array}{c}\text { Fiat } \\
\text { (B etim-M G / } \\
\text { Paulo Cam ilo) }\end{array}$ & $\begin{array}{c}\text { Fiat } \\
\text { (B etim-M G / } \\
\text { Paulo Cam ilo) }\end{array}$ \\
\hline Motorola & $\begin{array}{l}\text { G ene ral M otors } \\
(\text { S ão Caetanodo } \\
\text { Sul-SP) }\end{array}$ & $\begin{array}{c}\text { Fiat } \\
(\text { Betim-M G } \\
\text { Paulo Cam ilo) }\end{array}$ & R en a ult & R en a ult \\
\hline $\begin{array}{l}\text { G eneral M otors } \\
\text { (S ão José dos } \\
\text { C ampos-S P) }\end{array}$ & M ercedes-Benz & Re n au $1 \mathrm{t}$ & $\begin{array}{l}\text { Ge neral M otors } \\
(\text { S ão Ca etano do } \\
\text { Sul-SP) }\end{array}$ & $\begin{array}{l}\text { General M otors } \\
\text { (S ão Caetano do } \\
\text { Sul-SP) }\end{array}$ \\
\hline $\begin{array}{c}\text { General M otors } \\
\text { (São Caetano do } \\
\text { Sul-SP) }\end{array}$ & $\begin{array}{l}\text { G ene ral M otors } \\
\text { (S ão José dos } \\
\text { C a mpos-SP) }\end{array}$ & $\begin{array}{l}\text { Gen eral Motors } \\
(\text { São C a e tano do } \\
\text { S u l - S P) }\end{array}$ & $\begin{array}{l}\text { General Motors } \\
\text { (S ão José dos } \\
\text { C am pos-S P) }\end{array}$ & $\begin{array}{l}\text { Ge neral M otors } \\
\text { (S ão José dos } \\
\text { Campos-S P) }\end{array}$ \\
\hline R en a ult & Ren ault & $\begin{array}{c}\text { Volkswagen } \\
(\text { São B ernardo do } \\
\text { Cam po-SP) }\end{array}$ & M e rcedes-Ben z & $\begin{array}{c}\text { Fiat } \\
\text { (B etim - M G / } \\
\text { D istrito Industrial) }\end{array}$ \\
\hline D aim lerchrysler & $\begin{array}{l}\text { Volkswagen } \\
(\text { Taubaté - SP ) }\end{array}$ & Odebrecht & $\begin{array}{l}\text { Volkswage } \\
(\text { São B ernardo do } \\
\text { C am po-S P) }\end{array}$ & $\begin{array}{c}\text { Volkswage n } \\
(\text { São B ernardo do } \\
\text { C ampo-S P ) }\end{array}$ \\
\hline $\begin{array}{l}\text { Volkswage n } \\
(\text { Ta ubaté - SP) }\end{array}$ & To yota & T o yota & $\begin{array}{l}\text { Volks wagen } \\
(\text { T a ubaté - SP ) }\end{array}$ & M e rcedes-Ben z \\
\hline To y o ta & $\begin{array}{c}\text { Ford } \\
(\text { S ão Be rnardo do } \\
\text { C am po-SP) }\end{array}$ & $\begin{array}{l}\text { Volkswagen } \\
(\text { T auba té - S P) }\end{array}$ & T o y ot a & Petrobras \\
\hline $\begin{array}{c}\text { Ford } \\
(\mathrm{C} \text { am açari }-\mathrm{B} A)\end{array}$ & M oto ro la & $\begin{array}{c}\text { Ford } \\
(\mathrm{C} \text { am açari - B A ) }\end{array}$ & C ien & Peugeot-Citroen \\
\hline $\begin{array}{c}\text { Ford } \\
(\text { S ão Bernardo do } \\
\text { C ampo-SP) }\end{array}$ & $\begin{array}{c}\text { Ford } \\
(\mathrm{C} \text { am açari - B A })\end{array}$ & M otorola & $\begin{array}{c}\text { Ford } \\
(\mathrm{C} \text { a maça ri }-\mathrm{B} A)\end{array}$ & $\begin{array}{l}\text { Volkswage n } \\
(\text { Taubaté - SP) }\end{array}$ \\
\hline Petrobras & Petrobras & M ercedes-B enz & $\begin{array}{c}\text { Ford } \\
(\text { São B ernardo do } \\
\text { C ampo-S P ) } \\
\end{array}$ & $\begin{array}{c}\text { Ford } \\
(\text { São B ernardo do } \\
\text { C ampo-S P) }\end{array}$ \\
\hline Peuge ot-Citroen & $\begin{array}{l}\text { Volkswagen } \\
(\text { S ão Bernardo do } \\
\text { C am po-SP) }\end{array}$ & $\begin{array}{l}\text { Gen eral Motors } \\
(\text { São José dos } \\
\text { Campos-SP) }\end{array}$ & Em braer & E m brae $r$ \\
\hline
\end{tabular}

Fonte: SECEX, 2012.

[SYN]THESIS, Rio de Janeiro, vol.8, nº 1, 2015, p. 93 - 111 
A Tabela 9 contém, em ordem decrescente, as empresas no Brasil que mais importaram da Argentina, em valores acima de US\$ 50 milhões, no período de 2007 até 2011. Do mesmo modo que na tabela anterior, as empresas com mais de uma unidade de produção presentes no ranking foram listadas com a respectiva cidade e estado onde estão instaladas.

Tabela 9 - Empresas do Brasil que mais importaram da Argentina (continua)

\begin{tabular}{|c|c|c|c|c|}
\hline \multicolumn{5}{|c|}{ Empresas do Brasil que mais importaram da Argentina (acima de US\$ 50 milhões) } \\
\hline 2007 & 2008 & 2009 & 2010 & 2011 \\
\hline Toyota & Toyota & Toyota & Toyota & Toyota \\
\hline Copesul & Copesul & Fiat & Ford & Fiat \\
\hline Cisa Trading & Peugeot-Citroen & Ford & Fiat & Ford \\
\hline Ford & Ford & Peugeot-Citroen & Peugeot-Citroen & Cisa Trading \\
\hline $\begin{array}{c}\text { Petrobras (Osório } \\
\text { - RS) }\end{array}$ & Cisa Trading & $\begin{array}{c}\text { Volkswagen (São } \\
\text { José dos Pinhais - } \\
\text { RS) }\end{array}$ & Cisa Trading & Peugeot-Citroen \\
\hline $\begin{array}{c}\text { Volkswagen (São } \\
\text { José dos Pinhais - } \\
\text { RS) }\end{array}$ & $\begin{array}{c}\text { Volkswagen (São } \\
\text { José dos Pinhais - } \\
\text { RS) }\end{array}$ & Cisa Trading & $\begin{array}{c}\text { Volkswagen (São } \\
\text { José dos Pinhais - } \\
\text { RS) }\end{array}$ & $\begin{array}{c}\text { Volkswagen (São } \\
\text { José dos Pinhais - } \\
\text { RS) }\end{array}$ \\
\hline Peugeot-Citroen & Fiat & Renault & Braskem & Renault \\
\hline $\begin{array}{c}\text { Petrobras (Santos } \\
\text { - SP) }\end{array}$ & $\begin{array}{c}\text { Petrobras (Osório } \\
\text { - RS) }\end{array}$ & $\begin{array}{c}\text { Petrobras (Osório - } \\
\text { RS) }\end{array}$ & Renault & Braskem \\
\hline Dow Brasil & Iveco & Braskem & $\begin{array}{c}\text { Petrobras } \\
\text { (Osório-RS) }\end{array}$ & $\begin{array}{c}\text { Petrobras } \\
\text { (Osório-RS) }\end{array}$ \\
\hline Fiat & Renault & Dow Brasil & Mercedes-Benz & $\begin{array}{c}\text { Petrobras } \\
(\text { Santos - SP) }\end{array}$ \\
\hline Scania & Braskem & $\begin{array}{c}\text { Petrobras (Santos - } \\
\text { SP) }\end{array}$ & Dow Brasil & Mercedes-Benz \\
\hline Daimlerchrysler & Dow Brasil & Mercedes-Benz & Iveco & Dow Brasil \\
\hline Renault & Mercedes-Benz & $\begin{array}{c}\text { Petrobras } \\
\text { (São Francisco do } \\
\text { Conde - BA) }\end{array}$ & Scania & Iveco \\
\hline Caraíba & Atanor & $\begin{array}{l}\text { Volkswagen } \\
\text { (Taubaté - SP) }\end{array}$ & $\begin{array}{c}\text { Petrobrás } \\
(\text { Santos - SP) }\end{array}$ & Scania \\
\hline Braskem & Scania & Refap & $\begin{array}{c}\text { Volkswagen } \\
\text { (São Bernardo do } \\
\text { Campo - SP) }\end{array}$ & $\begin{array}{c}\text { Volkswagen } \\
\text { (São Bernardo do } \\
\text { Campo - SP) }\end{array}$ \\
\hline
\end{tabular}


Tabela 9 - Empresas do Brasil que mais importaram da Argentina (continuação)

\begin{tabular}{|c|c|c|c|c|}
\hline \multicolumn{5}{|c|}{ Empresas do Brasil qu mais im portaram da Argentina (acima de US\$50 milhões) } \\
\hline 2007 & 2008 & 2009 & 2010 & 2011 \\
\hline C araíb a & A tanor & $\begin{array}{l}\text { Volkswagen } \\
(\text { T aubaté - S P) }\end{array}$ & $\begin{array}{c}\text { Pe trobrá s } \\
(\text { Santos - SP) }\end{array}$ & Sc an ia \\
\hline Braskem & Sc an ia & $R$ efa $p$ & $\begin{array}{c}\text { Volks wagen } \\
(\text { Sa o Bernardo do } \\
\text { Campo-S P) }\end{array}$ & $\begin{array}{c}\text { Volkswagen } \\
(\text { Sa o B ern ardo do } \\
\text { Cam po-SP) }\end{array}$ \\
\hline
\end{tabular}

Fonte: SECEX, 2012.

\subsubsection{TERMOS DE TROCA}

Os termos de troca referem-se à razão entre os preços dos produtos exportados e os preços dos produtos importados. Nessa parte, o intercâmbio entre Brasil e Argentina deve ser detalhado quanto ao que constitui as importações e exportações, ou seja, a natureza dos produtos comercializados.

Caracterizando produtos como primários ou industrializados e adotando o referencial teórico da Comissão Econômica para a América Latina e Caribe (CEPAL), considera-se que produtos primários (ou básicos) sofrem deterioração histórica em seus termos de troca em relação a produtos industrializados devido à baixa expansão do consumo dos primeiros considerados os últimos. Desse modo, países que se voltassem para a especialização produtiva em produtos básicos se encontrariam em eterna desvantagem com relação a países que se dedicassem à produção de manufaturados.

Primeiro, deve-se considerar que o conceito de exportações por fator agregado, empregado na caracterização das mercadorias na balança comercial brasileira, envolve o agrupamento dos produtos em três grandes classes, levando-se em conta a maior ou menor quantidade de transformação (agregação de valor) que a mercadoria sofreu durante o seu processo produtivo, até a venda final. A primeira grande classe é constituída por produtos básicos, que são de baixo valor e normalmente intensivos em mão de obra, de cadeia produtiva simples e que sofrem poucas transformações. Como exemplos, podemos citar o minério de ferro e os grãos. A segunda classe corresponde aos produtos semimanufaturados, produtos que passaram por alguma transformação. É o caso do suco de laranja congelado e do couro. A terceira e última classe compreende os produtos manufaturados, normalmente de maior índice tecnológico e com alto valor agregado, como os televisores, chips de computador e automóveis.

Esse agrupamento é um pouco diferente no caso argentino, que considera seus produtos em três categorias: básicos, manufaturados (separados os de origem agropecuária dos de origem industrial) e combustíveis e energia.

Durante os anos 60, a pauta de exportações brasileiras se caracterizava por ser essencialmente constituída por produtos primários, enquanto o país importava, em sua grande maioria, produtos industrializados. Entretanto, a partir da década de 1980, a pauta de exportações do Brasil para Argentina, e para o mundo em geral, sofreu alterações e houve uma queda na importância dos produtos primários e um incremento significativo na participação dos produtos industrializados. Esse fato deve-se principalmente ao fortalecimento da indústria nacional brasileira, em vias de desenvolvimento desde a década de 1930, e que em 1980 já se mostra integrada e diferenciada. Essa característica das exportações brasileiras pode ser notada com o auxílio da Tabela 10, na qual se observa a participação percentual de produtos básicos, semimanufaturados, manufaturados e outros nas exportações brasileiras para a Argentina. O perfil destas exportações é caracterizado crescentemente por produtos manufaturados. 
Tabela 10 - Exportações brasileiras para a Argentina por fator agregado

\section{Exportações brasil ei ras para a Argentina por fator agregado (em \%)}

\begin{tabular}{c|c|c|c|c}
\hline Ano & Produtos básicos & Semimanufaturados & Manufaturados & Outros \\
\hline 1991 & 12,7 & 4,2 & 82,9 & 0,2 \\
\hline 1992 & 8,2 & 2,8 & 89 & 0,1 \\
\hline 1993 & 8,3 & 3,4 & 87,9 & 0,4 \\
\hline 1994 & 6,8 & 5,1 & 87,8 & 0,3 \\
\hline 1995 & 7,6 & 5 & 87 & 0,4 \\
\hline 1996 & 7,3 & 3,4 & 89,1 & 0,2 \\
\hline 1997 & 6,2 & 3,7 & 90 & 0,1 \\
\hline 1998 & 6,6 & 3,6 & 89,7 & 0,1 \\
\hline 1999 & 6,2 & 2,9 & 90,4 & 0,5 \\
\hline 2000 & 5,6 & 2,3 & 91,7 & 0,4 \\
\hline 2001 & 7,3 & 2,7 & 89,7 & 0,3 \\
\hline 2002 & 9,4 & 4,6 & 85,4 & 0,6 \\
\hline 2003 & 7,2 & 3,5 & 88,9 & 0,4 \\
\hline 2004 & 4,6 & 3,7 & 91,3 & 0,4 \\
\hline 2005 & 4,7 & 3 & 92 & 0,3 \\
\hline 2006 & 4,6 & 3,2 & 91,8 & 0,4 \\
\hline 2007 & 3,9 & 2,9 & 93 & 0,2 \\
\hline 2008 & 4,9 & 3,2 & 91,7 & 0,2 \\
\hline 2009 & 3,1 & 1,9 & 94,8 & 0,2 \\
\hline 2010 & 6,3 & 2,6 & 90,9 & 0,2 \\
\hline 2011 & 7,6 & 2,3 & 89,9 & 0,2 \\
\hline
\end{tabular}

Fonte: SECEX, 2012.

Vale dizer que do ponto de vista do comércio exterior brasileiro, a composição predominante de produtos manufaturados é uma realidade apenas na relação com a Argentina e no espaço do Mercosul em geral. Em seu conjunto, as exportações brasileiras têm um baixo coeficiente de produtos mais elaborados ou com maior conteúdo tecnológico. Aliás, nos últimos anos tem havido expansão do peso relativo e absoluto das commodities na pauta brasileira, principalmente nos últimos 15 anos, representando um processo de reprimarização. Durante os anos 90 , a participação destes produtos nas exportações brasileiras oscilava ao redor dos 40\%. Entre 2007 e 2010, esta participação saltou 10 pontos percentuais, alcançando $51 \%$ das exportações brasileiras, fortemente puxada pela exportação de minério de ferro.

Cabe ressaltar, neste caso específico, o desempenho de economias como a China, grande demandante de produtos agrícolas e minerais brasileiros. Este país, com um longo processo de urbanização pela frente, contribuiu de forma expressiva para o crescimento da participação de produtos primários na pauta de exportações brasileiras. Entre 2008 e 2009, no auge da crise financeira, as exportações brasileiras caíram de US\$ 197 bilhões para US\$ 152 bilhões, ao mesmo tempo em que as exportações brasileiras para a China predominantemente commodities - cresceram de US\$ 16 bilhões para mais de US $\$ 20$ bilhões (DE NEGRI e ALVARENGA, 2011).

Segundo dados da SECEX, o valor das exportações de produtos básicos em 2010 apresentou variação positiva de $45,3 \%$ em relação a 2009, enquanto a exportação brasileira de produtos manufaturados cresceu metade 
desse valor, $22,7 \%$, no mesmo período. Dados do montante dessa realidade podem ser visualizados por meio do Gráfico 15, que representa a evolução das exportações brasileiras.

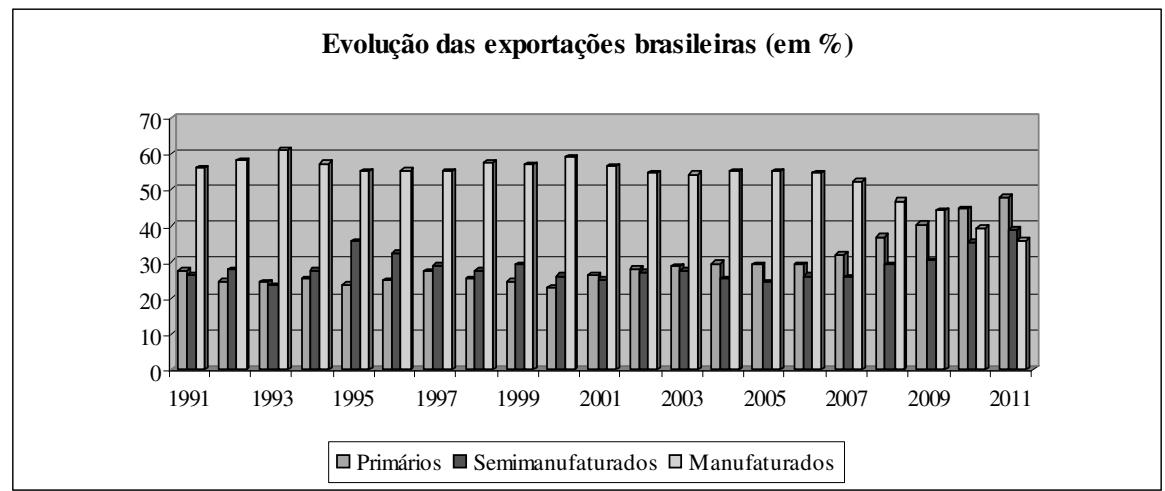

Gráfico 5 - Evolução das exportações brasileiras

Fonte: SECEX, 2011.

O processo de reprimarização descrito no caso brasileiro não pode ser observado na estimação da balança comercial argentina, ancorada essencialmente em produtos manufaturados, apesar da queda da participação destes no ano de 2010.

A economia argentina baseia-se, principalmente, na produção agrícola e na pecuária, que, juntas, respondem por $60 \%$ de seu PIB, considerando conjuntamente produtos primários e processados. $\mathrm{O}$ país, exatamente por isso, é uma das principais nações produtoras de carne, cereais e azeite do mundo, embora estes produtos sejam de pequena relevância para o intercâmbio com o Brasil, com destaque apenas para o trigo. Seu setor industrial mais importante é o de processamento e embalagem de produtos alimentícios, seguido pelo setor têxtil e pela indústria automobilística, esta última de inegável papel na balança comercial brasileira.

Em 2009, a porcentagem de produtos primários exportados pela Argentina era da ordem de 16,6\% do total exportado, enquanto a porção que cabia a produtos manufaturados de origem agropecuária ou industrial representava 71,8\%. Apesar da inegável preponderância dos manufaturados na matriz exportadora da Argentina, em 2010 a exportação de primários respondeu por $22,2 \%$ do total, ao passo que a parte correspondente de bens industrializados apresentou decréscimo e representou $68,2 \%$ do total. O Gráfico 6 permite constatar a evolução das exportações argentinas no que tange à natureza de seus produtos:

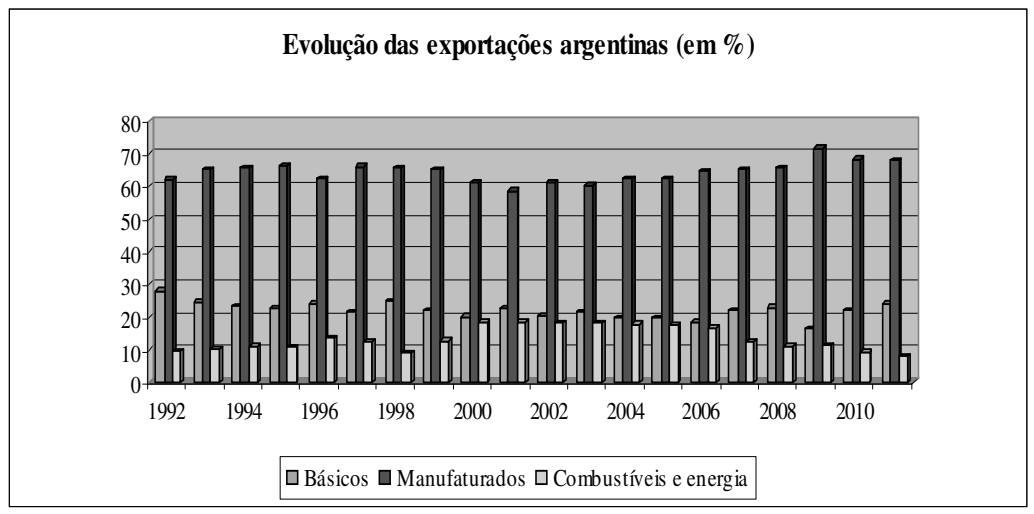

Gráfico 6-Evolução das exportações argentinas

Fonte: INDEC, 2011. 


\section{Considerações FINAIS}

De acordo com Moniz Bandeira, apenas Brasil, Estados Unidos e China estão, ao mesmo tempo, na relação dos dez países de maior território, dos dez países mais populosos e dos dez países de maior PIB do mundo. Nos últimos 100 anos, o PIB brasileiro foi aquele que apresentou o maior crescimento no mundo, o que significa expressiva acumulação de capital, capacidade tecnológica adquirida por empresários, engenheiros e operários e, portanto, a possibilidade de se expandir e se diversificar. Além disso, uma situação geográfica com $14.000 \mathrm{~km}$ de fronteiras terrestres com dez países, de tamanho médio ou pequeno, nenhum deles com território ou população superior a $20 \%$ do Brasil, com exceção da Argentina, e sem que existam fronteiras disputadas, confere ao país uma expressão geopolítica de grande relevância e uma possibilidade de ação política internacional correspondente. Porém, para tanto, é necessária uma maior aproximação com seu principal parceiro comercial sul-americano, a Argentina, iniciativa já iniciada com as repercussões positivas da criação do Mercosul. É indiscutível que a construção de vínculos estreitos de cooperação política e econômica entre Brasil e Argentina, com o objetivo de fortalecimento tecnológico, político, militar e econômico e de redução de sua dependência externa, criaria, com o tempo, um centro de poder na América do Sul que afetaria profundamente a dinâmica mundial.

A relação bilateral Brasil-Argentina sempre apresentou certas peculiaridades que não se verificam no intercâmbio desses países com o resto do mundo. Exemplos disso são verificados na balança comercial dos mesmos. Enquanto no Brasil o grupo de produtos industrializados respondeu por metade do total exportado no ano de 2011, na comparação com 2010, partindo da análise de crescimento percentual, as vendas de produtos básicos cresceram $36,1 \%$, e os semimanufaturados e os manufaturados se ampliaram em, respectivamente, $27,7 \%$ e $16 \%$, configurando uma reprimarização da pauta exportadora. Apesar disso, na relação com a Argentina, há a predominância de manufaturados e não de produtos básicos. $\mathrm{Na}$ mesma linha de análise, enquanto na Argentina os grupos de produtos que se referem à agricultura e à pecuária respondem por cerca de $60 \%$ dos volumes transacionados, no comércio com o vizinho brasileiro, os itens de maior destaque são os do setor industrial, particularmente da indústria automobilística, com exceção para o trigo (sempre com papel relevante).

Brasil e Argentina, em sua relação comercial mútua, são pontos discrepantes das suas dinâmicas no comércio mundial. Apoiar-se nesses pontos e fortalecer-se reciprocamente podem abrir o caminho para alcançar uma maior visibilidade e melhoria de condições de seus respectivos territórios e população.

\section{REFERÊNCIAS BibLIOGRÁFICAS}

ARGENTINA. Instituto Nacional de Estadística Y Censos (Indec). Estimación del Balance de Pagos. Disponível em: <http:// www.indec.mecon.ar>. Acessos em: jul. 2011/maio 2012.

AVERBUG, A. Mercosul: Conjuntura e Perspectivas. Revista do $B N D E S$, Rio de Janeiro, n.10, p. 1-15, 1998.

BANCO CENTRAL DO BRASIL. SML - Sistema de Pagamentos em Moeda Local. Disponível em: <http:// www.bcb.gov.br/?SML>. Acesso em: fev. 2012.

BRASIL. Ministério do Desenvolvimento, Indústria e Comércio Exterior. Secretaria do Desenvolvimento da Produção. Anuário Estatístico 2011. Disponível em:

$<$ http://www.mdic.gov.br//sitio/interna/interna.php? area=2 \&menu=1479>. Acesso em: jul. 2011.

BRASIL. Ministério do Desenvolvimento, Indústria e Comércio Exterior. Secretaria de Comércio Exterior (SECEX). Balança Comercial - Dados Consolidados. Disponível em: <http:// w w w. m dic.gov.br//sitio/interna/interna .php?area=5\&menu=571>. Acessos em: jul. 2011/maio 2012.

Conhecendo o Brasil em Números. Disponível em: $<$ http://www.mdic.gov.br//sitio/interna/interna.php? area=5\&menu=2701 > . Acessos em: jul. 2011/maio 2012.

Empresas brasileiras importadoras e exportadoras. Disponível em: <http://www.mdic.gov.br//sitio/interna/ interna.php?area=5\&menu=603 > . Acessos em: jul. 2011/maio 2012.

Evolução das exportações brasileiras por porte de empresa. Disponível em: <http://www.mdic.gov.br//sitio/ interna/interna.php?area $=5 \&$ menu $=3287 \&$ refr $=608>$. Acesso em: maio 2012.

Evolução das exportações brasileiras por fator agregado de 1964 em diante. Disponível em: 
<ht tp://www.mdic.gov.br//sitio/interna/ interna.php?area $=5 \&$ menu $=1846 \& \mathrm{refr}=608>$. Acesso em: nov. 2011.

Intercâmbio Comercial Brasileiro: países e blocos econômicos. Disponível em: <http://www.mdic.gov.br//sitio/ interna/interna.php?area=5\&menu=576>. Acessos em: jul. 2011/maio 2012.

BUENAS noticias made in Brazil. Página 12. Disponível em: $<$ http://www.pagina12.com.ar/diario/economia/2-190569-201203-28.html>. Acesso em: abr. 2012.

COMÉRCIO entre Brasil e Argentina é recorde em julho. Gazeta Online. Disponível em: <http://gazetaonline.globo.com/ _conteudo/2011/08/noticias/minuto_a_minuto/nacional/921079comercio-entre-brasil-e-argentina-e-recorde-em-julho.html> . Acesso em: set. 2011.

DE NEGRI, F. e ALVARENGA, G. V. A Primarização da Pauta de Exportações no Brasil: Ainda um Dilema. Radar: tecnologia, produção e comércio exterior, IPEA Brasília, n. 13, p. 7-14, abr. 2011.

DUNNING, J. H. Trade, location of economic activity and the multinational enterprise: a search for an eclectic approach. In: OHLIN, B.; HESSELBORN, P.D.; WIJKMAN, P.M. (Ed.). The international allocation of economic activity. London: Macmillan, 1977.

GONÇALVES, R. Economia Política Internacional: Fundamentos Teóricos e as Relações Internacionais do Brasil. 1. ed. Rio de Janeiro: Elsevier, 2005.

GUEDES, C. A. M. Notas para a proposta de disciplina Innovaciones, Integración Regional e Internacionalización encaminhadas para o Programa Binacional de Doctorado en Ciencia, Tecnología e Innovación Agropecuaria. UFRRJ/ UNRC, 2009.

GUEDES, C. A. M.; SILVA, R. Denominações territoriais agroalimentares, políticas e gestão social: Argentina, Brasil e a experiência espanhola no contexto europeu. In: JORNADAS INTERDISCIPLINARIAS DE ESTUDIOS AGRARIOS Y AGROINDUSTRIALES, 7., 2011, Buenos Aires. Anais... Buenos Aires: Editora da Universidad de Buenos Aires, 2011.

MACADAR, B. M. B. As relações comerciais Brasil-Argentina: evolução recente. Indicadores Econômicos FEE, v. 37, n. 2, 2009.

MERCOSUL completa 20 anos de integração econômica na região. Folha de São Paulo. Disponível em: <http:// www1.folha.uol.com.br/mundo/894398-mercosul-completa20-anos-de-integracao-economica-na-regiao.shtml>. Acesso em: out. 2011.

MERCOSUL. Sobre o Mercosul. Disponível em: <http:// www.mercosur.int>. Acesso em: fev. 2012.

MONIZ BANDEIRA, L. A. Brasil, Argentina e Estados Unidos: Conflito e Integração na América do Sul - Da Tríplice Aliança ao Mercosul. 3. ed. Rio de Janeiro: Civilização Brasileira, 2010.
SARAIVA, M. G.; ALMEIDA, F. R. F. A integração BrasilArgentina no final dos anos 90. Revista Brasileira de Política Internacional, v. 42, n. 2, p. 18-39, 1999. 